Original Research Paper

\title{
Curie Point Depth (CPD) Investigation Of Offshore Niger Delta Using High Resolution Aeromagnetic Data
}

\author{
Ofoha Chimezie Charles and Emujakporue Godwin Omokenu \\ Department of Physics, University of Port Harcourt, Rivers State, Nigeria
}

\author{
Article history \\ Received: 29-05-2017 \\ Revised: 04-10-2017 \\ Accepted: 06-01-2018 \\ Corresponding Author: \\ Ofoha Chimezie Charles \\ Department of Physics, \\ University of Port Harcourt, \\ Rivers State, Nigeria \\ Email: williamscharles333@yahoo.com
}

\section{Introduction}

Within the offshore Niger Delta, Nigerian province, there is a missing gap in the temperature study of the area by geoscientists via CPD estimation. The singular act of using aeromagnetic data to estimate the CPD has been in existence for some time and it has been applied to major basins of the world through the analysis of isolated magnetic anomalies due to discrete sources or through the frequency domain approach. Saibi et al. (2015) stated that the investigation of CPD began in the $19^{\text {th }}$ century. For instance, researchers like Bhattacharya and Leu (1975); Blakely (1996); Okubo et al. (1985); Tanaka et al. (1999); Rajaram et al. (2009) investigated the CPD within their respective areas of study. Based on the determined CPD values, geothermal exploration can be fostered. Nevertheless, geoscientists use mainly two

\begin{abstract}
Offshore Niger Delta, Nigeria, is known to be a hub for hydrocarbon exploration within the West Africa region and the world in general. The geologic settings within the Niger Delta province have a proven potential to assist in oil and gas exploration. However, much of the offshe provinces potential remains unknown with respect to the temperature differences using aeromagnetic data. In the present research, high resolution aeromagnetic data covering longitude $4^{0} 30^{\mathrm{i}} \mathrm{E}-5^{0} \mathrm{E}$ and latitude $3^{\circ} 30^{1} \mathrm{~N}-4^{0} 30 \mathrm{~N}$ with an approximate area of about $6050 \mathrm{~km}^{2}$ was used to estimate the Curie Point Depth (CPD) of the study area. For this aim to be realizable, regional-residual was undertaken on the Total Magnetic Intensity (TMI) data. This art gave rise to the regional and the residual maps. The residual map was then after divided into thirty five overlapping spectral grids. Spectral analysis was performed on each of the grids and this decomposed each grid into its energy and frequency segments. The results show three depth models, namely the depth due to the deeply sources, $D_{t}$ and the centroid depth, $D_{c}$, depth due to the shallow magnetic properties or the basal depth, $D_{b}$. However, $D_{c}$ varies from $-9950 \mathrm{~m}$ to $35294.12 \mathrm{~m}$ but with a true or average depth value of $-9751.75 \mathrm{~m}$ while $D_{t}$ lies between $-1250 \mathrm{~m}$ and -3684.21 but with a true depth of $-2000 \mathrm{~m}$. Similarly, the basal depth ranges from $-9950 \mathrm{~m}$ to $-35294.12 \mathrm{~m}$. This study therefore suggests that at a depth of $-9950 \mathrm{~m}$ and beyond ferromagnetic
\end{abstract} Keywords: CPD, TMI, Centroid Depth, Basal Depth, Absolute Noise Effect, Quantitative Analysis, Depth to Basement approaches to study the thermal structures inside the earth. These two (2) approaches, according to Saibi et al. (2015) are the direct and indirect methods. The direct method involves the direct measurement performed in boreholes while the method based on geophysical data analysis is known as the indirect method. In the indirect method, models from magnetic data are mostly used in estimating the CPD of an area. The indirect methods have several constraints such as depth resolution, which depends on the survey dimension and complexity of geological structures that can cause significant errors in the estimation of CPD (Okubo and Matsunaga, 1994). The CPD is the depth at which the dominant magnetic mineral in the crust passes from a ferromagnetic state to a paramagnetic state under the effect of increasing temperatures (Kasidi and Nur, 2013). 
In the present research, spectral depth analysis was exploited in estimating the CPD of the study area using a high resolution aeromagnetic data. This study will therefore add to the geophysical information of the area using the frequency domain approach. At the CPD, the temperature exceeds the curie temperature of $580^{\circ} \mathrm{C}$. Above such temperature, ferromagnetic materials lose their magnetism. According to Hinze et al. (2013), the loss in the magnetic properties of these ferromagnetic materials is due to the thermal energy maintaining a random alignment of the magnetic moments of iron minerals. So by estimating the lowest depth point of magnetized crust, the curie isotherm and temprature variations in the thickness of magnetized basement rocks can be explained explicitly.

\section{Location and Geologic Settings of Study Area}

The study area lies between longitude $4^{0} 30^{\mathrm{i}} \mathrm{E}-5^{0} \mathrm{E}$ and latitude $3^{\circ} 30^{\mathrm{i}} \mathrm{N}-4^{0} 30^{\mathrm{i}} \mathrm{N}$ with an approximate area of about $6050 \mathrm{~km}^{2}$ within the Niger Delta sedimentary basin of Nigeria, (Fig. 1). The Niger Delta is situated in the apex of the Gulf of Guinea on the west coast Africa. The stratigraphic and structural disposition of the Niger
Delta has been documented by several workers (Reijers, 1996). The Niger Delta was formed by the buildup of sediments over a crustal tract developed by rift faulting during the Precambrian with outlines controlled by deep seated faults associated with rifting (Weber and Daukoru, 1975). Rifting diminished in the late cretaceous and gravity tectonism became the primary deformational process after the rifting phase in the Niger Delta. The Niger Delta started as two different depocenters in the Bende-Ameki area, east of the Delta and in the Anambra shelves, west of the delta in the mid to late Eocene. These two depocenters later formed a single deltaic sedimentary basin in the late Miocene to date (Blakely, 1996).

The Tertiary section of the Niger Delta is divided into three Formations representing prograding depositional facies that are distinguished on the basis of sand-shale ratios to recent, namely: the Akata, Agbada and the Benin Formation. The Akata Formations, which is the potential source rock is estimated to be up to $7000 \mathrm{~m}$ thick while the Abgada and Benin Formation are estimated to be $3700 \mathrm{~m}$ and $2000 \mathrm{~m}$ thick respectively (Michele et al., 1999).

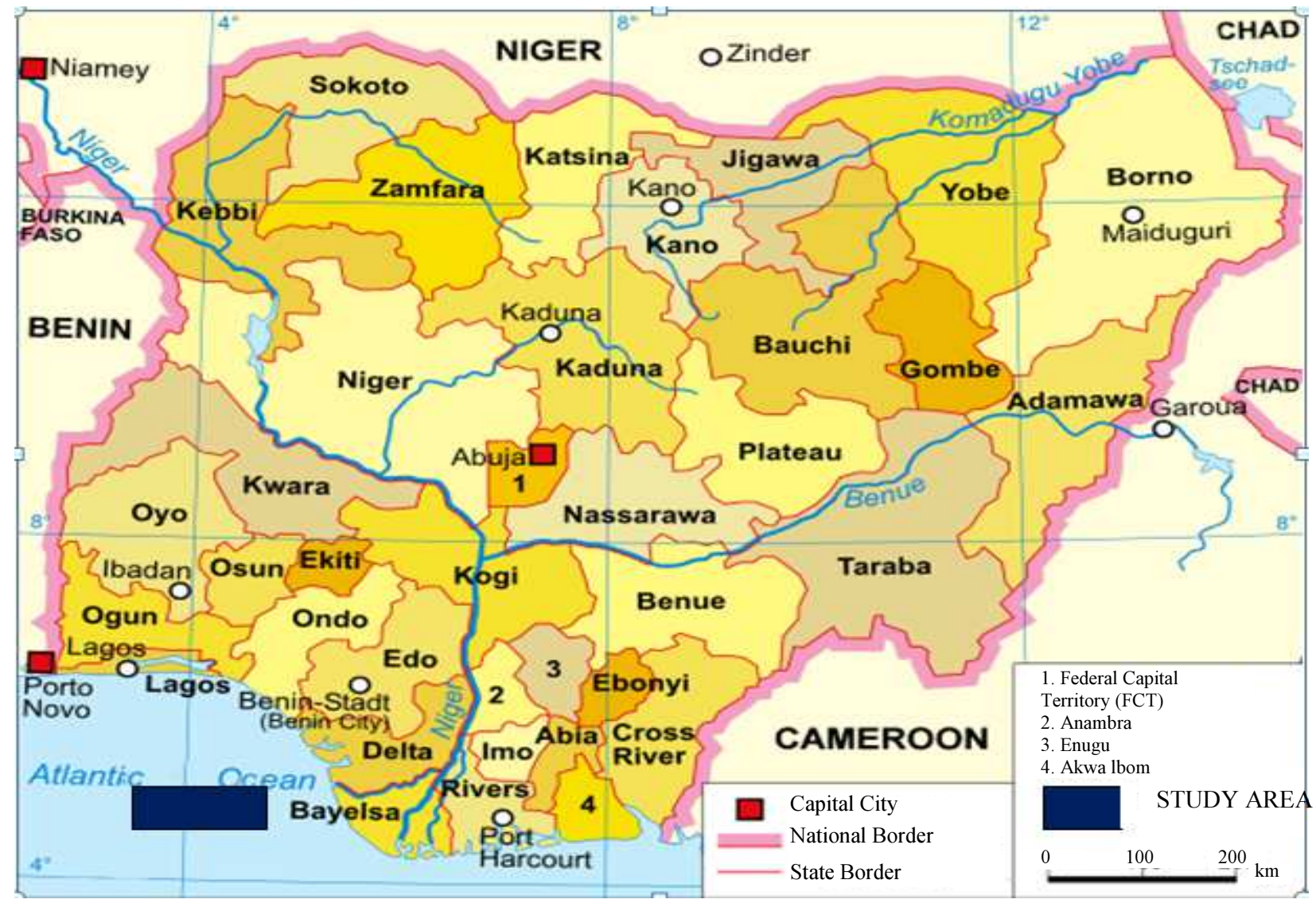

Fig. 1: Map of Nigeria and its environs showing the study area (after Doust and Omatsola, 1990) 


\section{Materials and Method}

Figure 2 represents the digitized total magnetic intensity map used for this study. The data with sheet number $333 \mathrm{~b}$ and 340 was sourced from the Nigerian Geological Survey Agency, NGSA. The data which covers an area of about $6052 \mathrm{~km}^{2}$ was acquired on a series of NW-SE flight lines in 2009 by Fugro Air born service. The total intensity aeromagnetic map is of high resolution than those of $1970 \mathrm{~s}$ in that it has a terrain clearance of $100 \mathrm{~m}$ and line spacing of $500 \mathrm{~m}$ while tie lines occur at about $20 \mathrm{~km}$. The WingLink, Ms Excel, ArcGIS, Surfer 10 and the Origin Pro 8 Geophysical software were used for the data analysis, processing and interpretation. To visualize the aeromagnetic data, the data saved in geosoft file format was opened with ArcGIS software and then converted into a format the WingLink can identify. The converted data was then imported into the WingLink software and the raster aeromagnetic data produced. Thereafter, the raster map transformed into its contour format. On the contour map, regional-residual separation was carried out and this gave rise to the regional and residual maps. The regional was ignored while the residual was subjected to further quantitative analysis. Geological insignificance was the reason behind the regional being discarded while the residual was of immense important geologically and economically as evidenced by the configuration of the contours. To quantitatively estimate the CPD value, the residual was sectioned into thirty five spectral windows or grids using the Ms Excel and fast fourier transform was then performed on each of the windows with the aid of the data analysis tool of the Ms Excel software. This decomposed each of the grids into its energy and frequency components. Log of the energy spectrum is plotted against frequency. A straight line is thereafter fitted into its high and low frequency components of the spectral energy curve. By dividing the negative slope of the low frequency parts of the energy curve by two (2), the sedimentary thickness is determined for each of the windows. These values represent the sedimentary thickness. Similarly, the slopes for each of the less steep energy curves determined and the values divided by two. Depth values estimated from the steepest energy curve are due to the low frequency components or the deep seated structures while the depth values associated with the less steep energy curve are due to the high frequency components or the shallow seated sources. The average values or the depth values at the center were obtained by summing the depth values due to the low and high frequency components and then dividing by two. The average depth value is located at the center point of each window. For this research, the depth values due to the low frequency component were taken as the depth to centroid $\left(Z_{c}\right)$ while the values obtained using the high frequency components were assumed to be the depth values due to the top of various magnetic sources $\left(Z_{t}\right)$. The determined $Z_{C}$ and $Z_{T}$ values were then substituted into equation 1 so as to calculate the basal depth. The basal depths calculated were therefore regarded as the CPD:

$Z_{b}=2 Z_{C}-Z_{t}$

Where:

$Z_{b}=$ The basal depth

$Z_{c}=$ The centroid dept

The determined centroid and basal depths were imported into surfer 10 environment for the $3 \mathrm{D}$ and contour maps to be generated.

\section{Results and Interpretation}

The raster map (Fig. 2) was transformed into a contour map (Fig. 3). Upon the contour map, regionalresidual separation was applied and this gave rise to the regional map (Fig. 4) and the residual map (Fig. 5). Fast Fourier Transform (FFT) was performed on the gridded residual (Fig. 5a) and then the spectral plots undertaken. The graphs in Fig. 5 b show some of the spectral plots or the log of Energy plotted against frequency. With the aid of the spectral plots, Table 1 which shows the various depth models was generated. $D_{c}, D_{t}$ and $D_{b}$ represent the centroid depth, the depth to the top of the magnetic sources and the basal depth respectively. $\mathrm{D}_{\mathrm{a}}$ depicts the average sedimentary thickness for each of the grids or windows. The average thickness was estimated to be at the center of the grid located at a point with the aid of the longititude and latitude values. The centroid depth $\left(D_{c}\right)$ is known as the depth to the basement or the sedimentary thickness values. $D_{c}$ is also known as the depth due to the deeply seated magnetic bodies while the $\left(D_{t}\right)$ is known as the depth due to the shallow magnetic bodies. The basal depth $\left(D_{b}\right)$ is the Curie Point Depth (CPD). The $D_{b}$ is mathemetically expressed in equation 1 . The depth to basement varies from $-5600 \mathrm{~m}$ to $-13636.4 \mathrm{~m}$ but with an average of $-9751.75 \mathrm{~m}$ while the depth of magnetic sources due to the shallow magnetic effects ranges from $-1250 \mathrm{~m}$ to $-3684.21 \mathrm{~m}$ but with an average of $-2000 \mathrm{~m}$. It is evident from the table that the minerals start losing their ferromagnetic property at a depth of $9950 \mathrm{~m}$ while at a maximum depth of $-35294.12 \mathrm{~m}$ the minerals are, perhaps, paramagnetic. Figuers 6 and 7 depict 3D map for the basal and centroid depth respectively. Similarly, Fig. 8 and 9 represent the contour map of the basal and centroid depth respectively. 
Ofoha Chimezie Charles and Emujakporue Godwin Omokenu / Current Research in Geoscience 2018, Volume 8: 14.26 DOI: 10.3844/ajgsp.2018.14.26

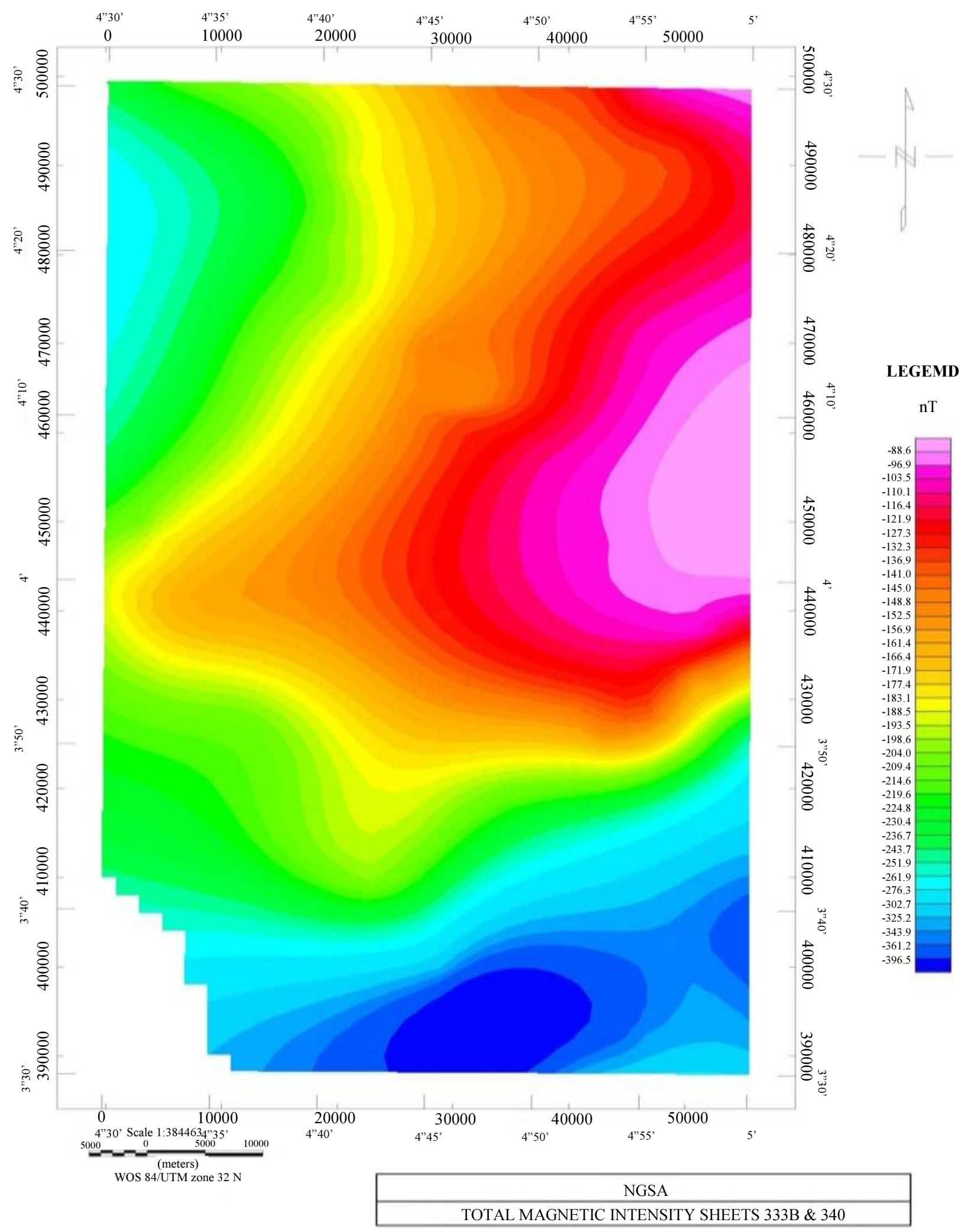

Fig. 2: Raster aeromagnetic map of the study area (nT) 


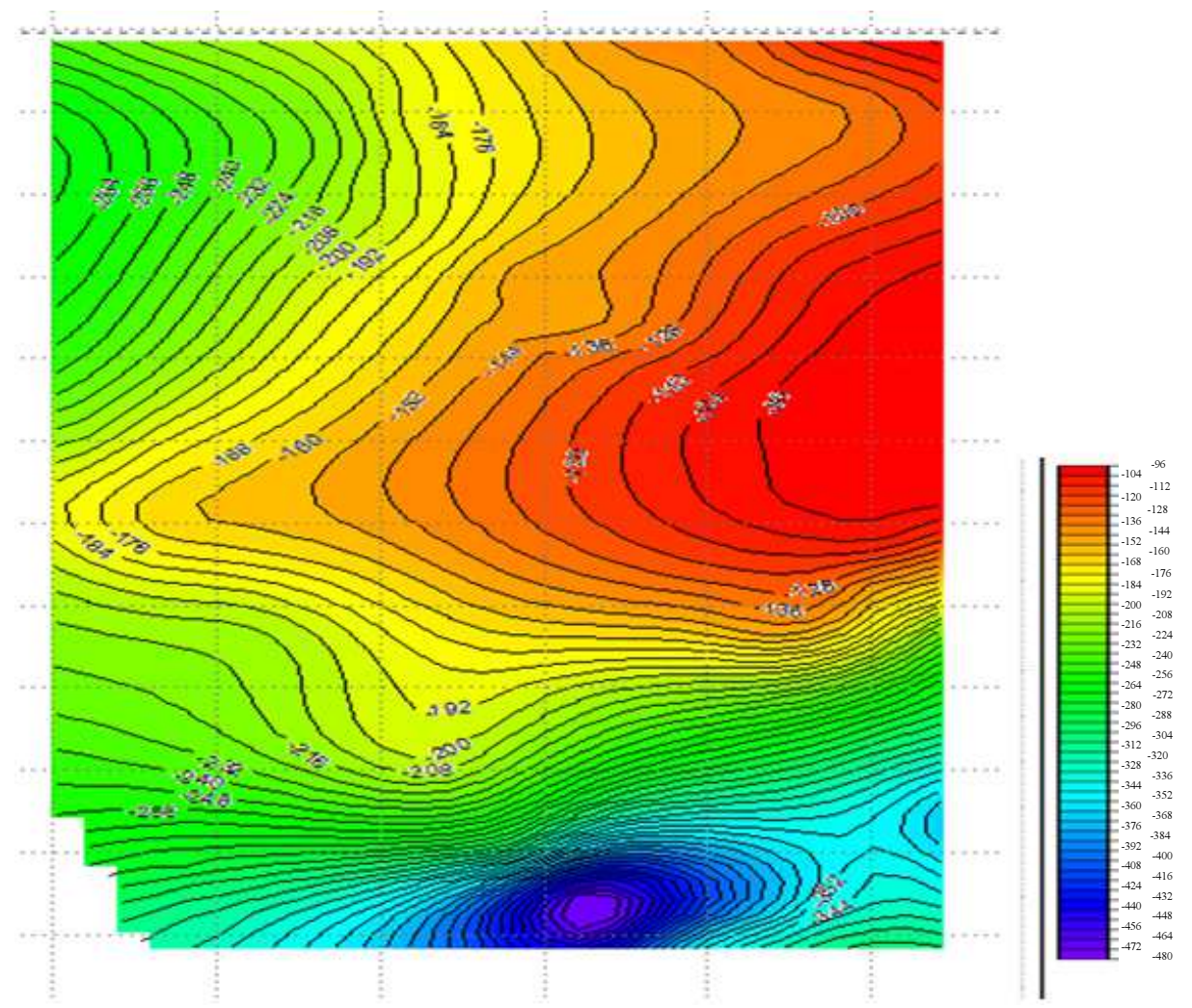

Fig. 3: Composite aeromagnetic map of the study area represented in contours (nT)

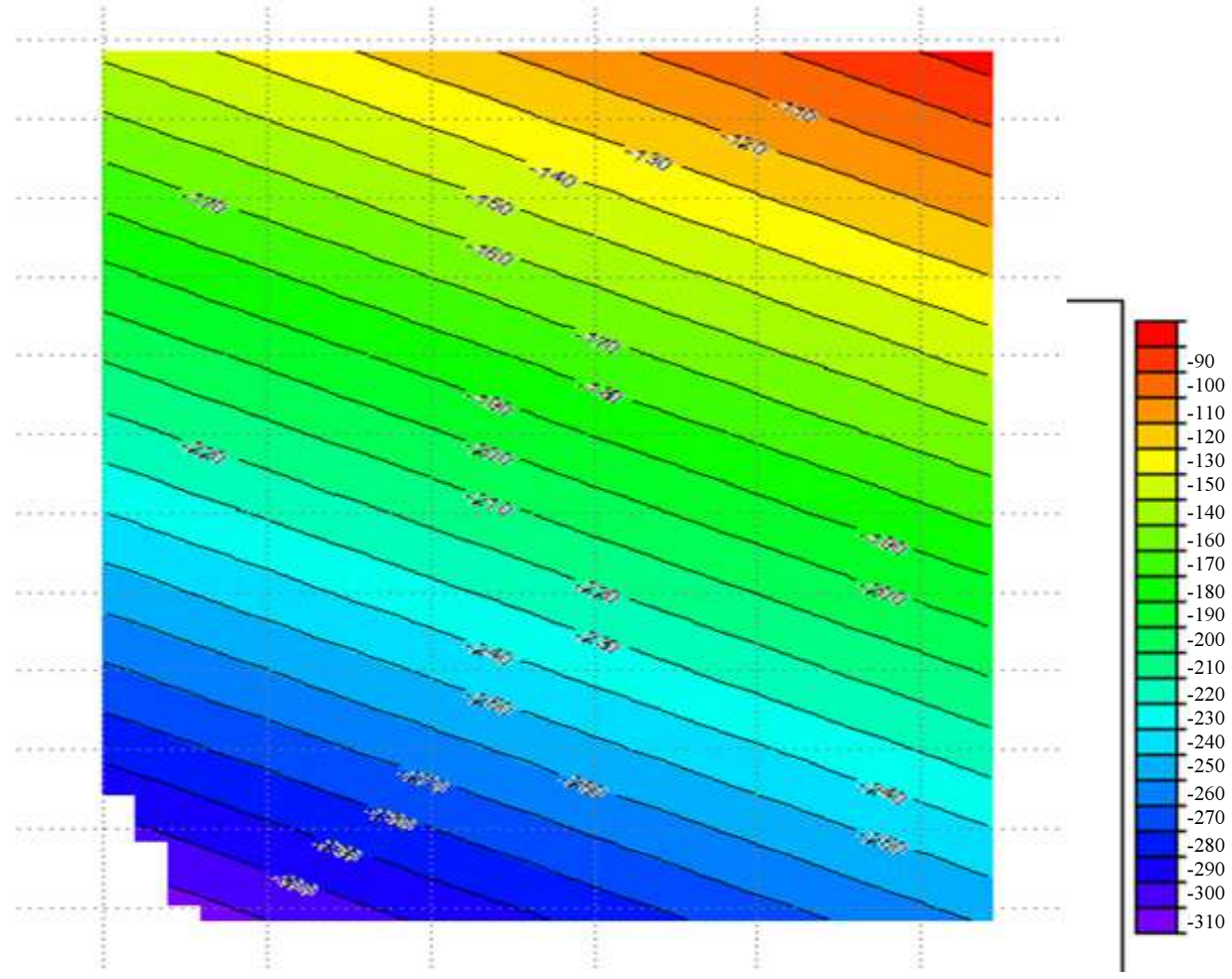

Fig. 4: Regional aeromagnetic map (nT) 


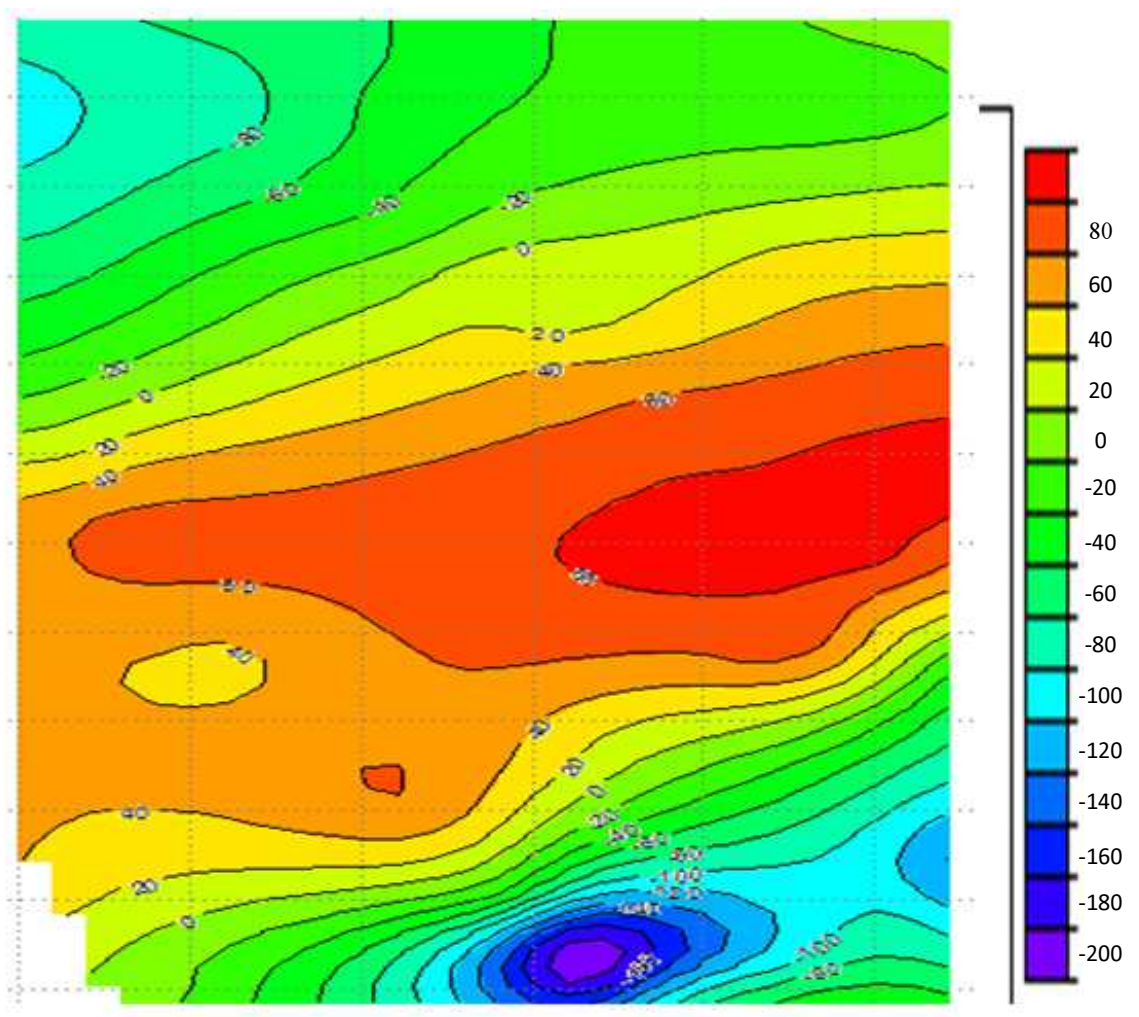

Fig. 5: Residual Aeromagnetic map of the study area (nT)

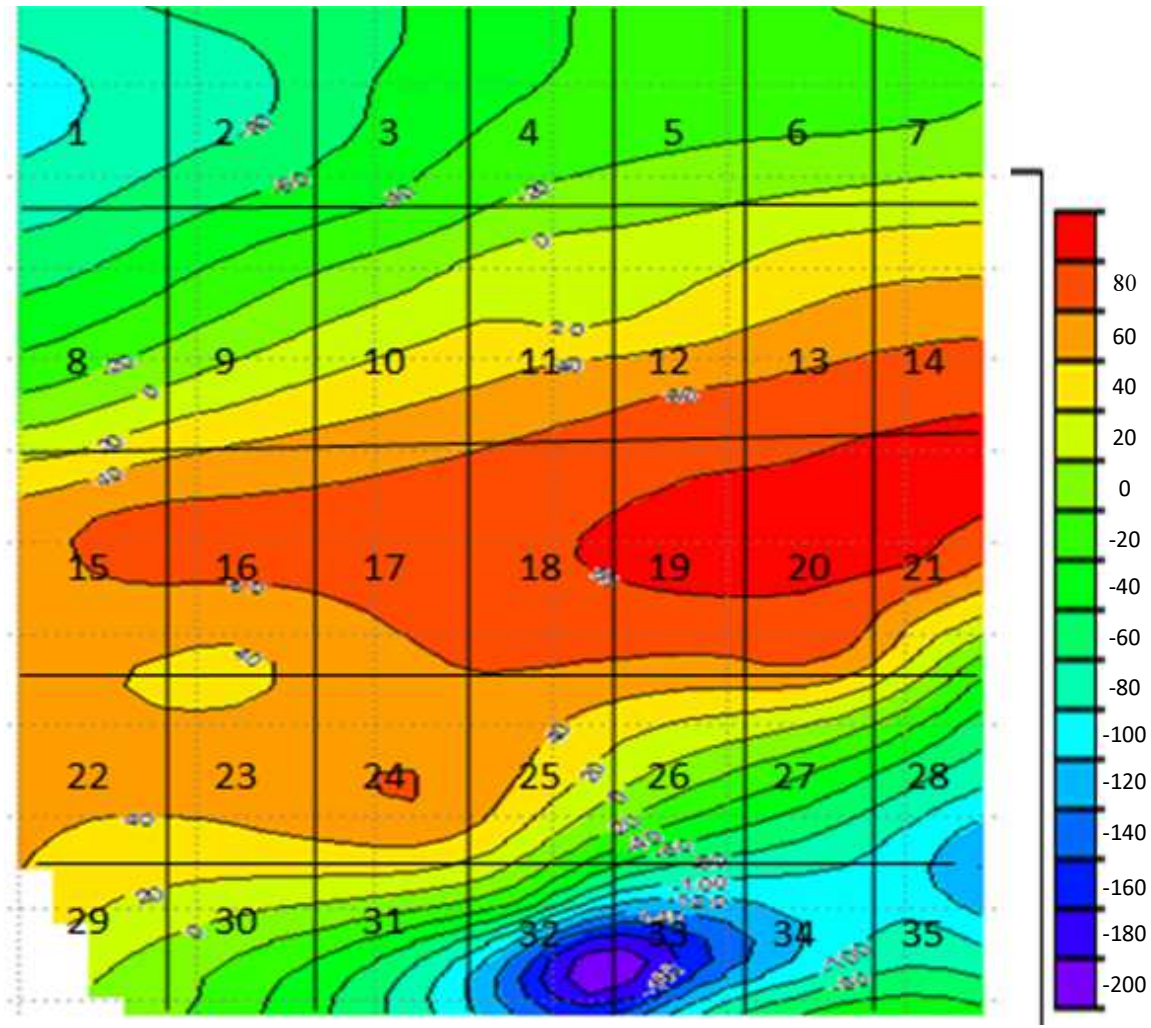

Fig. 5a: Residual aeromagnetic map divided into thirty five overlapping spectral grids (nT) 


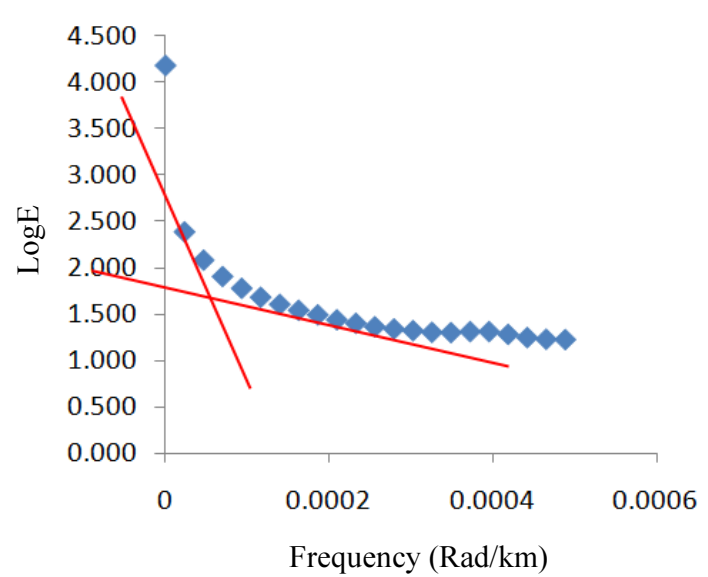

A graph showing depth for deep and shallow seated features for cell one

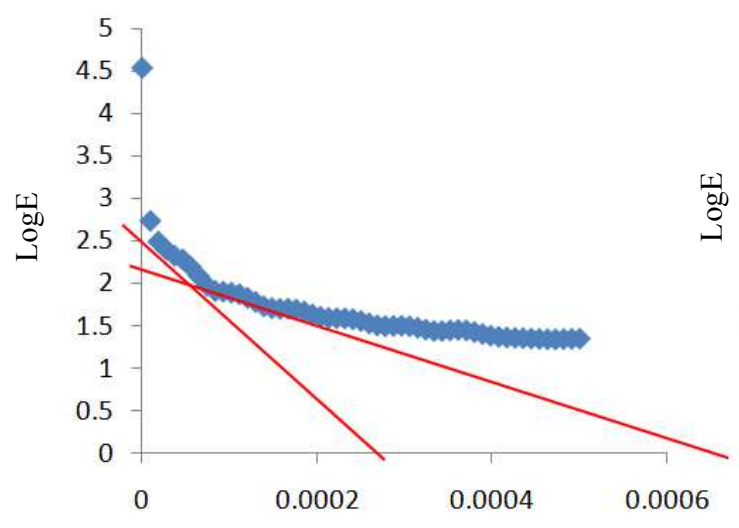

Frequency $(\operatorname{Rad} / \mathrm{km})$

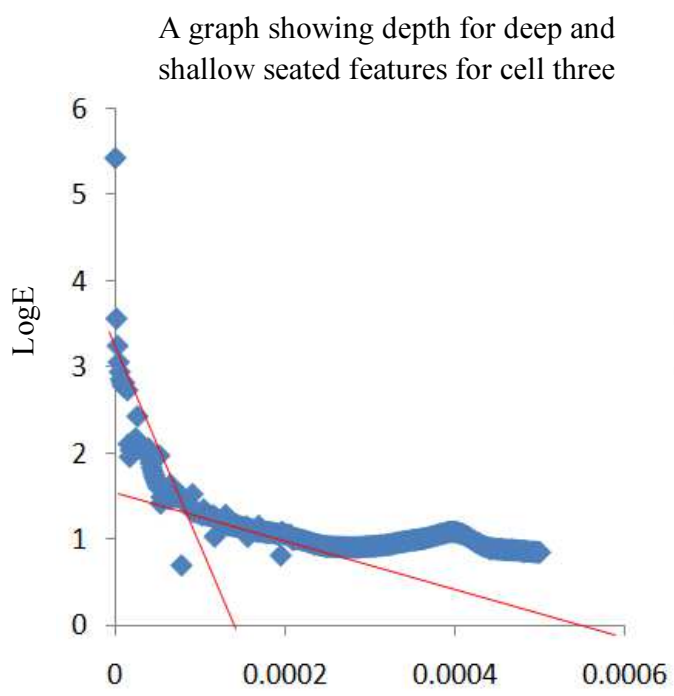

Frequency $(\operatorname{Rad} / \mathrm{km})$

A graph showing depth for deep and shallow seated features for cell five

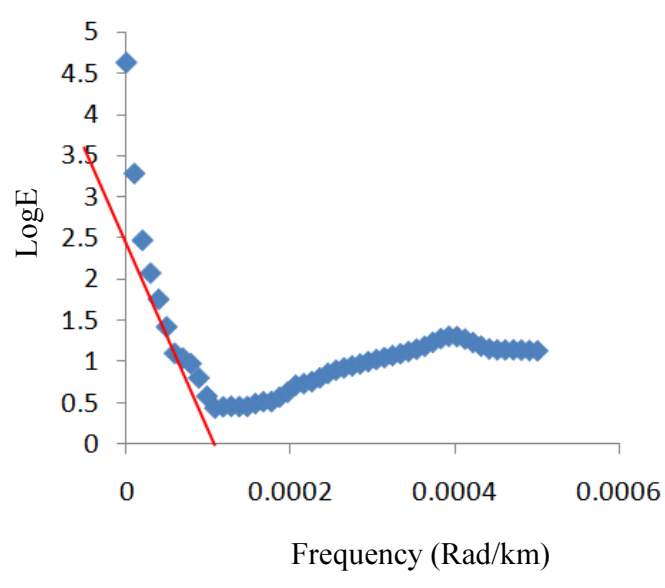

A graph showing depth for deep and shallow seated features for cell two

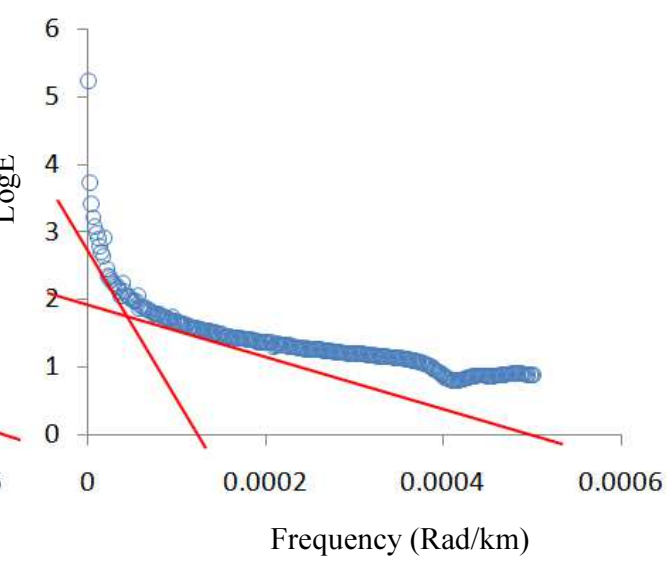

A graph showing depth for deep and shallow seated features for cell four

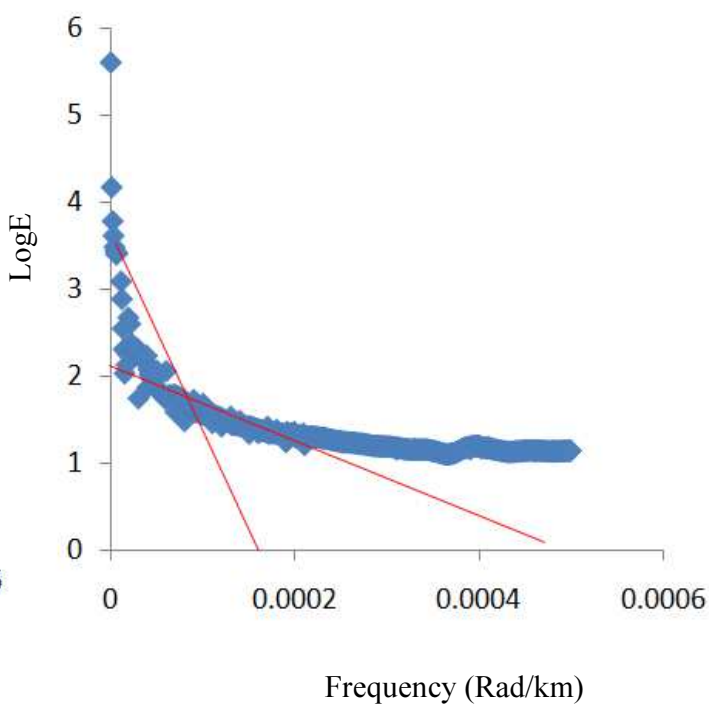

A graph showing depth for deep and shallow seated features for cell six 


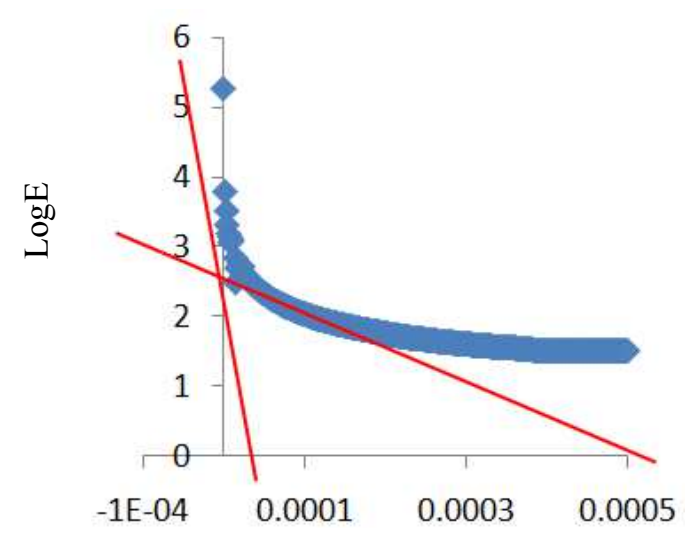

Frequency $(\operatorname{Rad} / \mathrm{km})$

A graph showing depth for deep and shallow seated features for cell seven

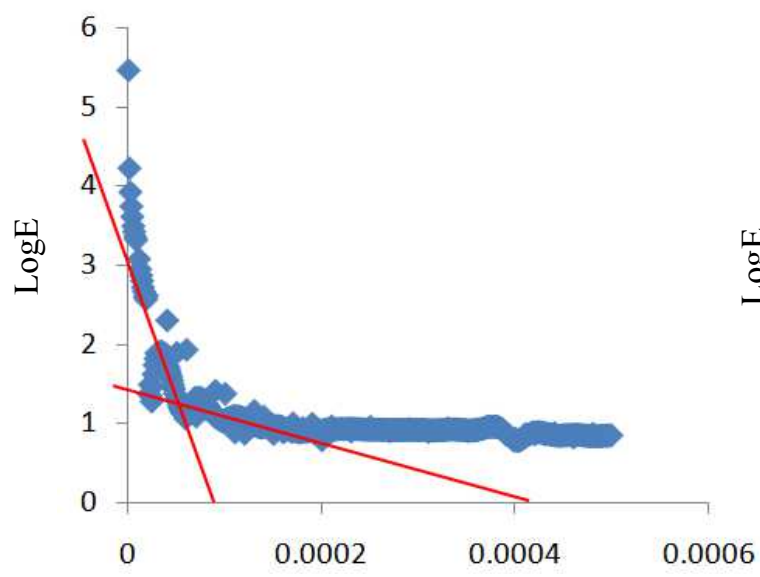

Frequency $(\operatorname{Rad} / \mathrm{km})$

A graph showing depth for deep and shallow seated features for cell nine

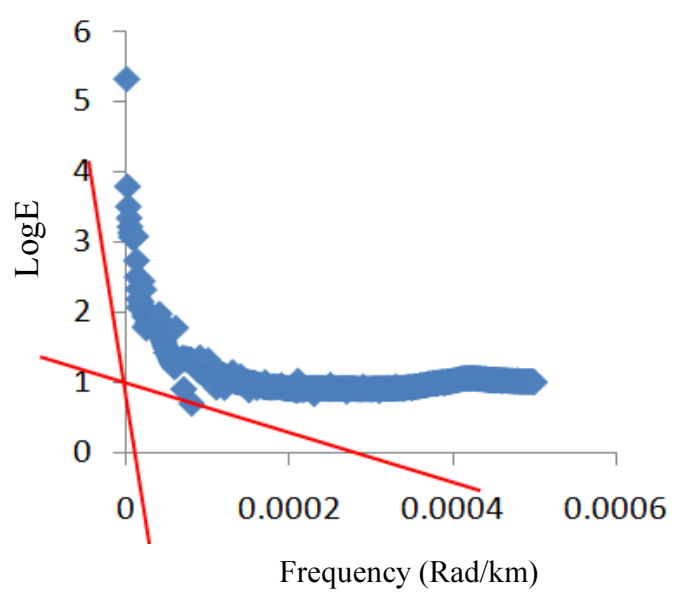

A graph showing depth for deep and shallow seated features for cell eleven

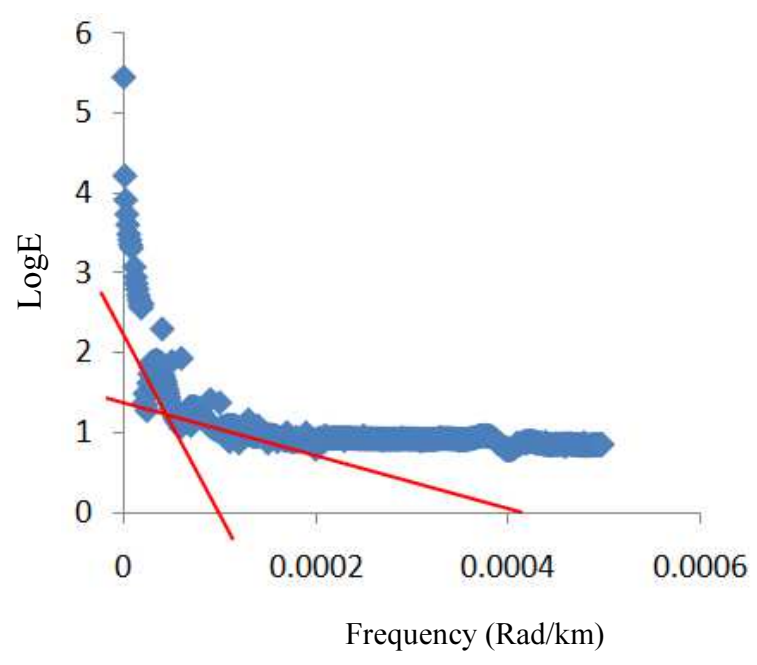

A graph showing depth for deep and shallow seated features for cell eight

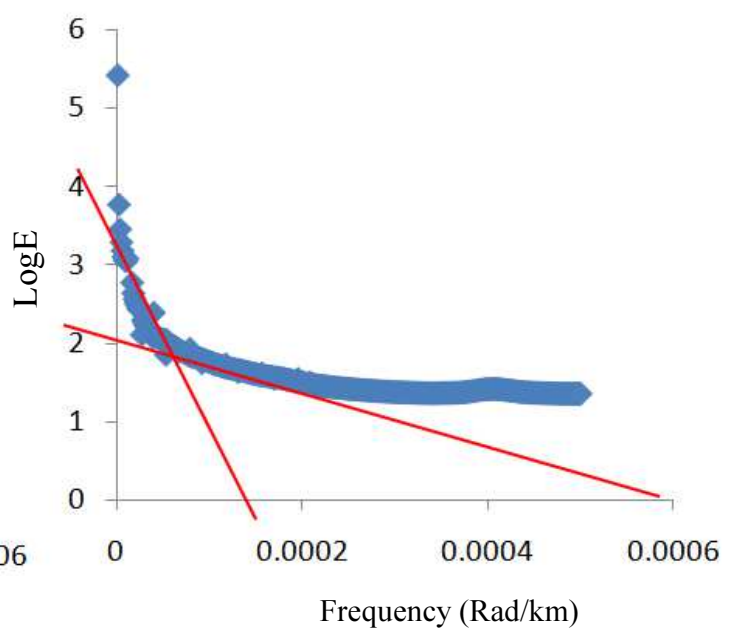

A graph showing depth for deep and shallow seated features for cell ten

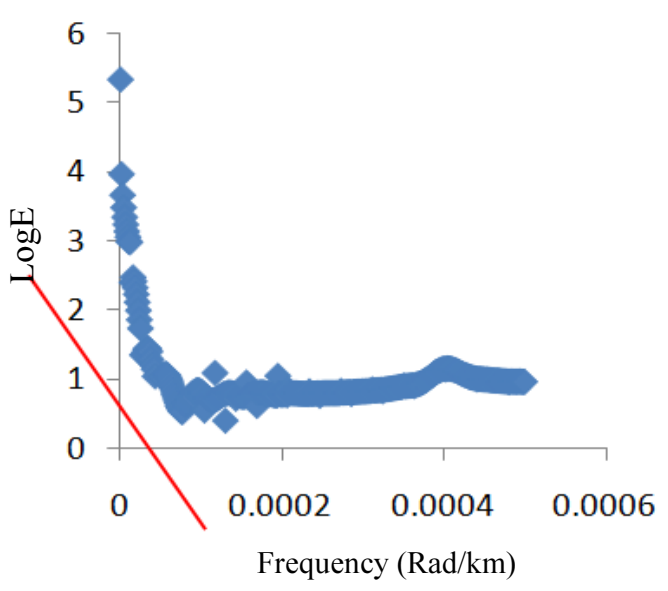

A graph showing depth for deep and shallow seated features for cell Ttwelve 


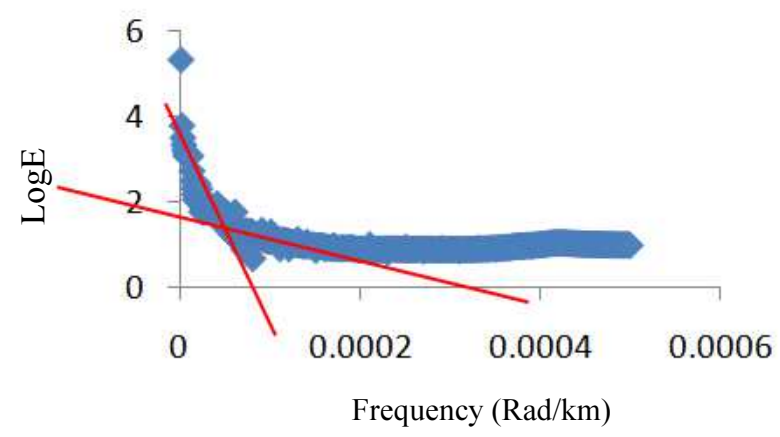

A graph showing depth for deep and shallow seated features for cell thirteen

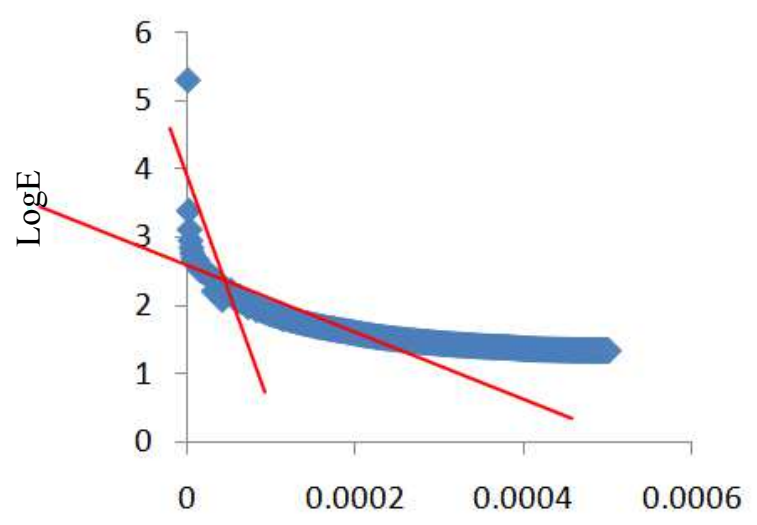

Frequency $(\operatorname{Rad} / \mathrm{km})$

A graph showing depth for deep and shallow seated features for cell fifteen

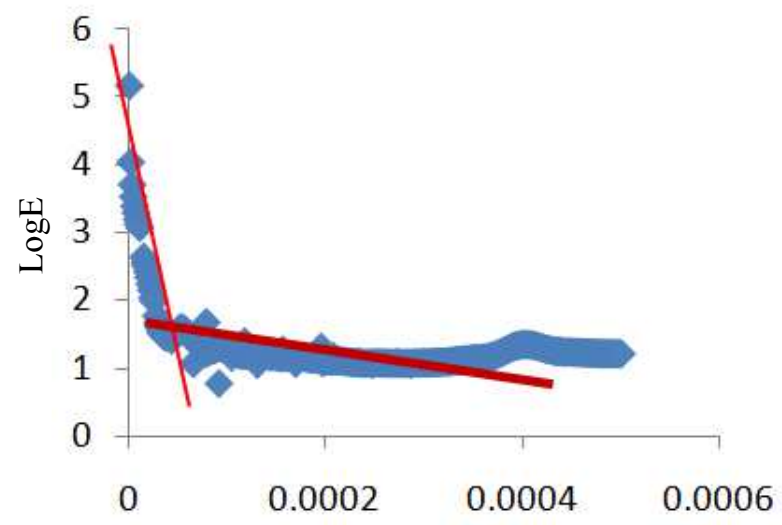

Frequency $(\mathrm{Rad} / \mathrm{km})$

A graph showing depth for deep and shallow seated features for cell seventeen

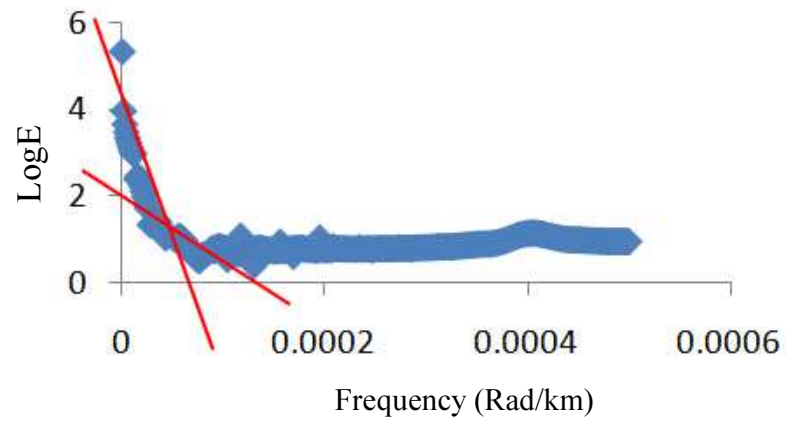

A graph showing depth for deep and shallow seated features for cell foutteen

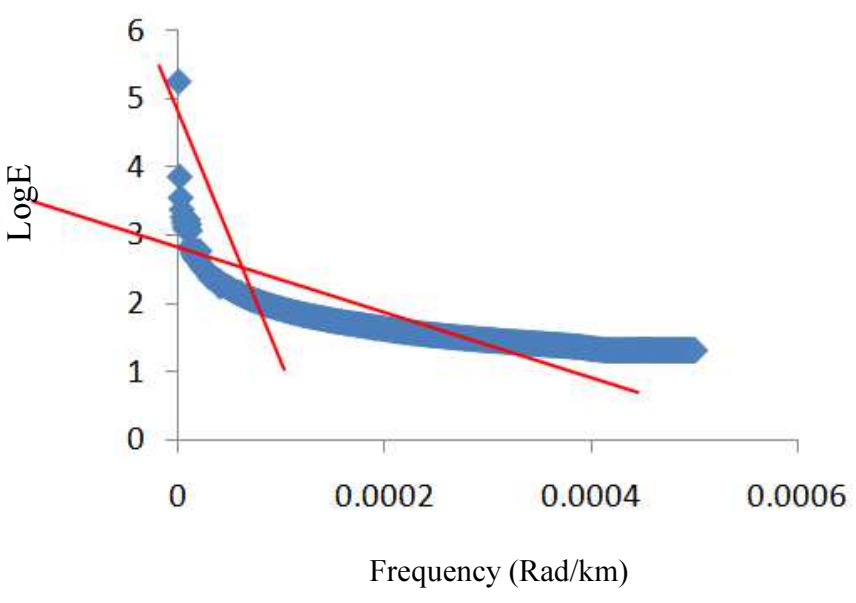

A graph showing depth for deep and shallow seated features for cell sixteen

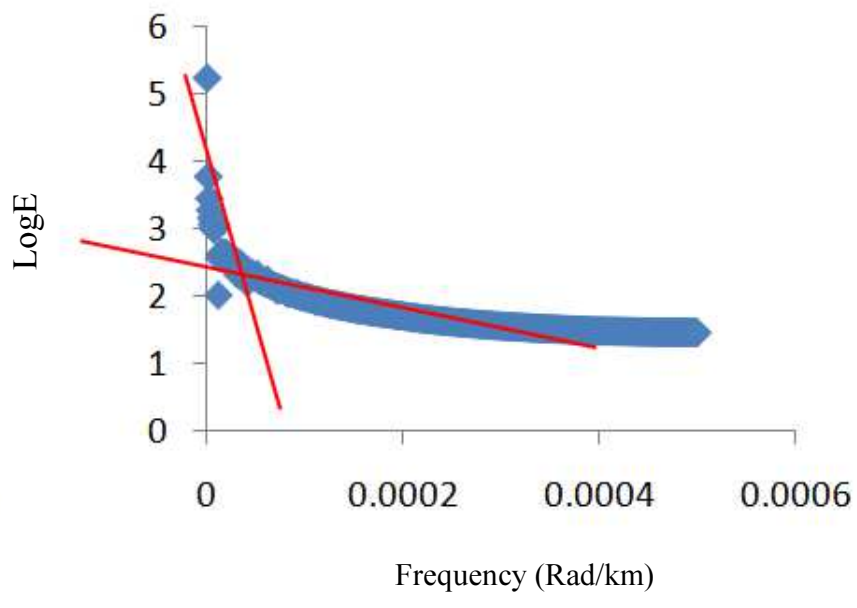

A graph showing depth for deep and shallow seated features for cell eighteen

Fig. 5b: Graphs showing the spectral energy curves for some of the grids 


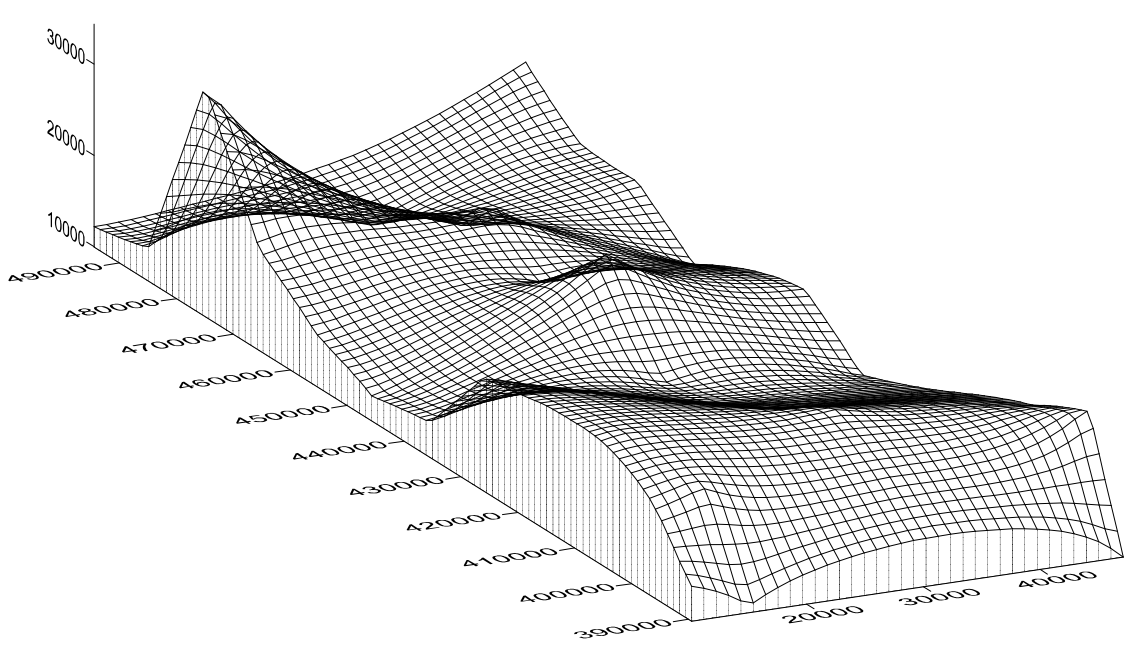

Fig. 6: 3D Wireframe Map Showing the Basal Depth (m)

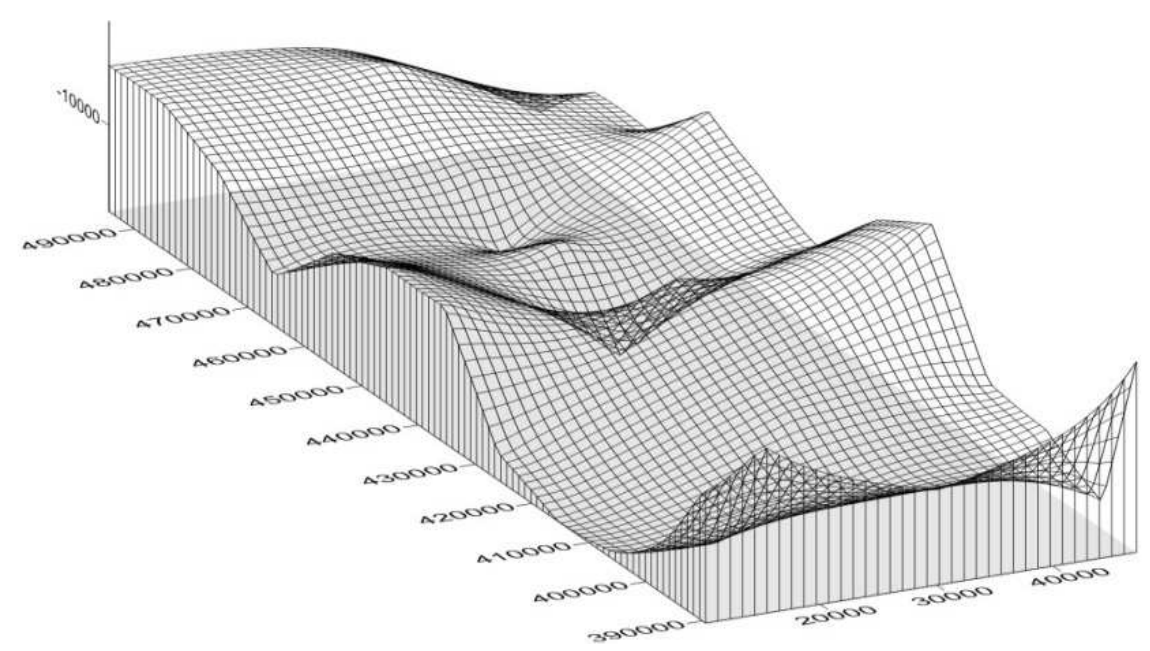

Fig. 7: 3D Wireframe map showing the centroid depth (m)

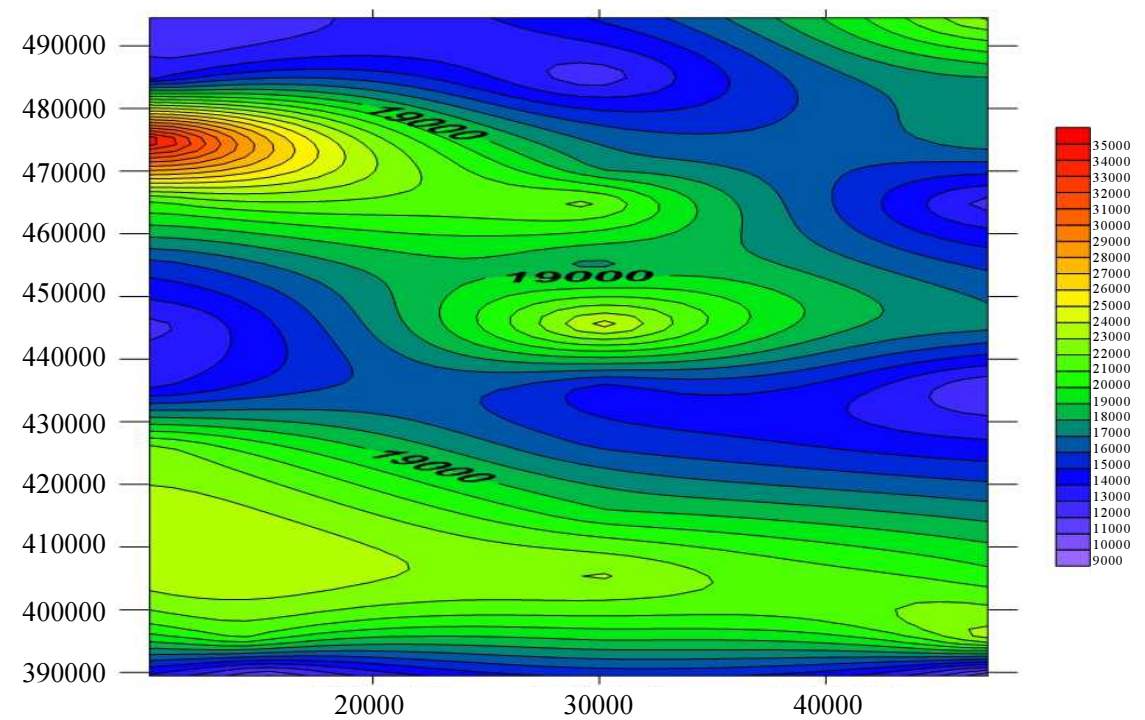

Fig. 8: Contour map showing the basal depth (m) 


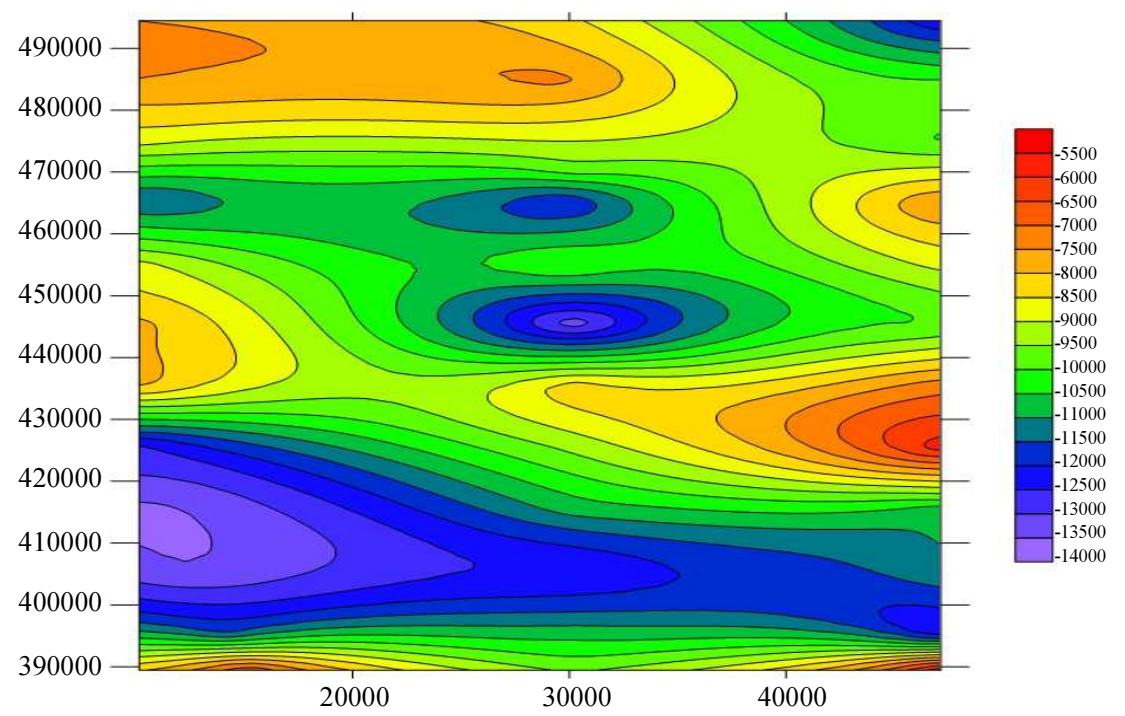

Fig. 9: Contour map showing the centroid depth (m)

Table 1: Various depth models of the study area

\begin{tabular}{|c|c|c|c|c|c|c|c|c|}
\hline \multirow[b]{2}{*}{ CELL/GRID } & \multirow[b]{2}{*}{ Longitude } & \multirow[b]{2}{*}{ Latitude } & \multicolumn{2}{|l|}{ Slope } & \multicolumn{2}{|c|}{ Depth (m) } & \multirow[b]{2}{*}{$D_{b}$} & \multirow[b]{2}{*}{$D_{a}$} \\
\hline & & & $M_{1}$ & $M_{2}$ & $D_{c}$ & $D_{t}$ & & \\
\hline 1 & 15150 & 389450 & -13138.10 & -4834.60 & -6569.05 & -2417.30 & -10720.8 & 8988.40 \\
\hline 2 & 30150 & 389450 & -19238.80 & & -9619.39 & & & \\
\hline 3 & 47150 & 389450 & -11200.00 & -2500.00 & -5600.00 & -1250.00 & -9950.0 & 3425.00 \\
\hline 4 & 14150 & 395450 & -23076.90 & -4000.00 & -11538.50 & -2000.00 & -21076.9 & 6769.30 \\
\hline 5 & 30150 & 395450 & -21428.60 & -4444.44 & -10714.30 & -2222.22 & -19206.4 & 6468.30 \\
\hline 6 & 47150 & 395450 & -25000.00 & -2941.10 & -12500.00 & -1470.59 & -23529.4 & 6985.30 \\
\hline 7 & 12150 & 405450 & -26923.10 & -6000.00 & -13461.50 & -3000.00 & -23923.1 & 8230.70 \\
\hline 8 & 30150 & 405450 & -25000.00 & -3750.00 & -12500.00 & -1875.00 & -23125.0 & 7187.50 \\
\hline 9 & 47150 & 405450 & -22140.90 & -3636.36 & -11071.40 & -1818.18 & -20324.7 & 11701.40 \\
\hline 10 & 10150 & 415450 & -27272.70 & -7368.42 & -13636.40 & -3684.21 & -23588.5 & 8660.30 \\
\hline 11 & 30150 & 415450 & -21538.50 & -4750.00 & -10769.20 & -2375.00 & -19163.5 & 6572.10 \\
\hline 12 & 47150 & 415450 & -21538.50 & & -10769.20 & & & \\
\hline 13 & 10150 & 425950 & -25000.00 & -5250.00 & -12500.00 & -2625.00 & -22375.0 & 7562.50 \\
\hline 14 & 29650 & 425950 & -18750.00 & -5555.56 & -9375.00 & -2777.78 & -15972.2 & 6076.39 \\
\hline 15 & 47150 & 425450 & -11500.00 & & -5750.00 & & & \\
\hline 16 & 10150 & 435450 & -15789.50 & -4000.00 & -7894.74 & -2000.00 & -13789.5 & 4947.40 \\
\hline 17 & 30150 & 435450 & -16483.50 & -4000.00 & -8241.76 & -2000.00 & -14483.5 & 5120.90 \\
\hline 18 & 47150 & 435450 & -14450.00 & 5000.00 & -7225.00 & -2500.00 & -11950.0 & 4862.50 \\
\hline 19 & 10150 & 445450 & -15789.50 & -6250.00 & -7894.74 & -3150.00 & -12639.5 & 5522.40 \\
\hline 20 & 30150 & 445450 & -26666.70 & -4200.00 & -13333.30 & -2100.00 & -24566.7 & 7716.70 \\
\hline 21 & 47150 & 445450 & -20000.00 & -5250.00 & -10000.00 & -2625.00 & -17375.0 & 6312.50 \\
\hline 22 & 10150 & 454950 & -17647.10 & -4285.71 & -8823.53 & -2142.85 & -15504.2 & 5483.20 \\
\hline 23 & 29650 & 454950 & -19867.00 & -4509.80 & -9933.77 & -2254.90 & -17612.6 & 6094.30 \\
\hline 24 & 47150 & 455450 & -17562.50 & -3800.00 & -8781.25 & -1900.00 & -15662.5 & 5340.80 \\
\hline 25 & 10150 & 465450 & -23076.90 & -4000.00 & -11538.50 & -2000.00 & -21076.9 & 6769.25 \\
\hline 26 & 29650 & 464950 & -24166.10 & -3636.36 & -12083.30 & -1818.18 & -22348.5 & 6950.70 \\
\hline 27 & 47150 & 464950 & -14950.00 & -4878.05 & -7475.00 & -2439.02 & -12511.0 & 4957.01 \\
\hline 28 & 10150 & 474950 & -17649.10 & -4400.00 & -8823.53 & -2200.00 & -35294.1 & 5511.80 \\
\hline 29 & 30150 & 470450 & -19411.80 & -3333.33 & -9705.00 & -1666.67 & -17743.3 & 5685.80 \\
\hline 30 & 47150 & 474950 & -20069.00 & -4634.15 & -10034.70 & -2317.07 & -17752.4 & 6175.90 \\
\hline 31 & 10150 & 484950 & -15000.00 & -2750.00 & -7500.00 & -1375.00 & -13625.0 & 4437.50 \\
\hline 32 & 29650 & 484950 & -14761.00 & -5000.00 & -7380.00 & -2500.00 & -12260.0 & 4940.00 \\
\hline 33 & 47150 & 484950 & -20000.00 & -4061.22 & -10000.00 & -2030.61 & -17969.4 & 6015.30 \\
\hline 34 & 10150 & 494450 & -25000.00 & -5600.00 & -7500.00 & -2800.00 & -12200.0 & 5150.00 \\
\hline 35 & 29650 & 494450 & -16666.70 & -3230.77 & -8333.33 & -1615.39 & -15051.2 & 4974.40 \\
\hline
\end{tabular}




\section{Discussion of Findings}

Ubiquitous on the aeromagnetic raster maps are colour variations depicting possible changes of the magnetic field within the study area. These field changes could be due to the presence of different minerals, presence of distinct lithology, presence of basement rocks as well as the presence of geologic boundary within the study area. With the aid of the colour contrast, the study area was remarked into high and low magnetic units. The magnetic high is indicated with the red and yellow colours while the magnetic low is represented with the green, light blue and the blue colours. The magnetic intensity values for each of the units are indicated with the legend beside the aeromagnetic raster map. For the magnetic high unit, the values ranges from $-184 \mathrm{nT}$ to $-90 \mathrm{nT}$. Magnetic values which falls within $-480 \mathrm{nT}$ to $-192 \mathrm{nT}$ indicate magnetic low. Generally, the Total Magnetic Intensity (TMI) ranges from $-480 \mathrm{n}$ T to $-90 \mathrm{nT}$.

On transforming the raster aeromagnetic map into a contour map, contours of various shapes and sizes are apparent. The contour map is a superimposition of the regional (the deeply seated) on the residual (the shallow seated) sources. The regional masks the residual that enhances the economic capability of the area. Hence, the need for regional-residual separation. Of most interest to geoscientists is the residual as it unveils possible economic deposits. This is evident with the nature of contours. The regional, nevertheless, is economically insignificant as evidenced with the elongated tectonic trends.

Further quantitative analysis was undertaken on the residual. This revealed three (3) depth models $D_{c}, D_{t}$ and the $D_{b}$. The depth to basement $\left(D_{c}\right)$ or the centroid depth varies from $-5600 \mathrm{~m}$ to $-13636.4 \mathrm{~m}$ but with a true depth of $-9751.75 \mathrm{~m}$. The deepest depth to basement occurred within the South Eastern portion of the study area seen in block 10. This was estimated to be $13636 \mathrm{~m}$. This maximum thickness value disagrees with the result obtained by Ali et al. (2012). They obtained the maximum thickness to be $10 \mathrm{~km}$ and this perfectly agrees with the thicknesses of grid 21 and 33. The depth to shallow sources for cell two, twelve and fifteen were not computed due to the absolute noise effect within the region. The result of the spectral analysis, however, shows alternating sedimentary thickness values as against the claim by Ako et al. (2014) who suggested that the sedimentary thickness within offshore Niger Delta increases southward. The 3D and contour maps depicting the basal and centroid depths illustrate the undulating nature of the basement morphology. The 3D maps show basement highs and lows. The basement highs and lows depicted in 3D map correspond to the basal and centroid contour maps in that the basement highs are represented with the yellow and orange colours while the lows are illustrated with the blue colours. The basements highs and lows form anticlinal and synclinal structures. The basement highs are formed possibly by igneous intrusive. The syncline or basement low formed by the frequent subjection of strata to compression is regarded as the generating depocenters as the oil and gas generated in such regional lows will migrate up dip. Generally, the contours in the depth to contour maps are relatively spaced and this signifies the basement complex region. The basement highs and lows will therefore encourage the possible trapping of hydrocarbon. The depth to the top of magnetic sources $\left(D_{t}\right)$ range from $1250 \mathrm{~m}$ to $-3684.21 \mathrm{~m}$ then with a true depth of $-2000 \mathrm{~m}$ while the basal depth falls within $-9950 \mathrm{~m}$ and $35294.12 \mathrm{~m}$. Shallower CPD values were remarked to range from $-9950 \mathrm{~m}$ to $-17969.39 \mathrm{~m}$ and these values are observed in grid 1, 3, 14, 16, 17, 18, 19, 21, 22, 23, 24, 27, $29,30,31,32,33,34$ and 35 . These shallow values can be associated with the thinning of the crust and recent upwelling of molten magma which lead to the formation of new crust within the study area. The deeper CPD values ranges from $-19163.46 \mathrm{~m}$ to $-35294.12 \mathrm{~m}$. These values can be seen in grid 4, 5, 6, 7, 8, 9, 10, 11, 20, 25, 26 and 28. In this study, the deep CPD reflects possible subduction zone. Grids with shallow CPD values are therefore suggested to be possible geothermal energy source due to the magmatic activity within the area.

\section{Conclusion}

The quantitative analysis undertaken in this research revealed sedimentary thickness values lying between $5600 \mathrm{~m}$ and $-13636.4 \mathrm{~m}$ but with an average of -9751.75 $\mathrm{m}$. In a similar vein, the depth of magnetic sources due to the shallow magnetic effects range from $-1250 \mathrm{~m}$ to $3684.21 \mathrm{~m}$ but with an average of $-2000 \mathrm{~m}$. Also it was established that at a depth of $9950 \mathrm{~m}$ and beyond, magnetic sources become paramagnetic. Hence an established average sedimentary thickness of about 9.8 $\mathrm{km}$ proposed the study area to foster the exploration and exploitation of hydrocarbon.

\section{Recommendation}

In view of the epileptic power supply in Nigeria, we recommend that the federal government of Nigeria should harness and exploit the geothermal energy potentials of the study area found within the offshore region of Nigeria. By exploiting the geothermal potentials of the area, the national grid output will be increased. This will in turn encourage industrialization that controls unemployment in the country. 


\section{Acknowledgement}

To the Nigerian Geological Survey Agency (NGSA), we say thank you for providing the data used for this work.

\section{Author's Contributions}

Ofoha Chimezie Charles: Carried out literature review, processed the data, presented and discussed the results.

Emujakporue Godwin Omokenu: He read and edited the manuscript.

\section{Ethics}

This article is original and contains unpublished material. The corresponding author confirms that all of the other authors have read and approved the manuscript and no ethical issues involved

\section{References}

Ako, B.D., S.B. Ojo, C.S. Okereke, T.R. Ajayi and A.A. Adepelumi et al., 2014. Some observations from gravity/magnetic data interpretation of the Niger Delta. Nigeria Association of Petroleum Explorationist Bull., 17: 11-12.

Ali, I., S. Olantunji, L.I. Nwankwo, C.O. Akoshile and L.M. Johnson et al., 2012. Geomagnetic modeling of potential hydrocarbon traps in the lower Niger Delta, offshore West Africa. Archives Applied Sci. Res., 4: 863-847.

Bhattacharya, B.K. and L.K. Leu, 1975. Analysis of magnetic anomalies over Yellowstone national park: Mapping the curie point depth isothermal surface for geothermal reconnaissance. J. Geophys. Res., 80: 4461-4465.

Blakely, R.J., 1996. Potential theory in Gravity and Magnetic Applications. 1st Edn., Cambridge University Press, Cambridge.

Doust, H. and E. Omatsola, 1990. Divergent passive Margin Basin, AAPG Memoir 48. Am. Association Geologists, 48: 42-55.
Hinze, W.J., R.R. Von Frese and A.H. Saad, 2013. Gravity and Magnetic Exploration: Principles, Practices and Applications. 1st Edn., Cambridge University Press, Cambridge, ISBN-10: 1107328195

Kasidi, S. and A. Nur, 2013. Estimation of Curie point depth, heat flow and geothermal gradient inferred from aeromagnetic data over Jalingo and environs North - Eastern Nigeria. Int. J. Sci. Emerging Tech., 6: 294-301.

Michele, L.W., R.C. Ronald and E.B. Micheal, 1999. The Niger delta petroleum system: Niger delta province, Nigeria, Cameroun and Equitorial Guinea, Africa. USGS Open Files Report.

Okubo, Y. and T. Matsunaga, 1994. Curie point depth in northeast Japan and its correlation with regional thermal structure and seismicity. J. Geophysical Res., 99: 17-24.

Okubo, Y., R.J. Graf, R.O. Hansen, K. Ogowa and H. Tsu, 1985. Curie point depth of the island of Kyushu and surrounding areas, Japan. Geophysics, 50: 481-494.

Rajaram, M., S.P. Anand, K. Hemant and M.E. Purucker, 2009. Curie Isotherm map of Indian subcontinent from satellite and aeromagnetic data. Earth Planetary Sci. Lett., 281: 3-4.

Reijers, T.J., 1996. Stratigraphy and sedimentation of Niger Delta. Geologos, 17: 136-158.

Saibi, H., E. Abound and M. Azizi, 2015. Curie depth point map for western Afghanistan deduced from the analysis of aeromagnetic data. Proceedings of the World Geothermal Congress, Melbourne, Apr. 1-12, Australia. pp: 1-12.

Tanaka, A., Y. Okuba and O. Matsubayashi, 1999. Curie point depth based on spectrum analysis of the magnetic anomaly data in East and Southeast Asia. Tectonophysics, 306: 461-470.

Weber, K.J. and E. Daukoru, 1975. Petroleum geology of the Niger Delta. Proceedings of the 9th World Petroleum Congress, May 11-16, Tokyo, Japan. 